\title{
Development and validation of enzyme-linked immunosorbent assay (ELISA) vitellogenin in Lates calcarifer.
}

\begin{abstract}
A study was conducted to develop and validate a competitive enzyme-linked immunosorbent assay (ELISA) for detection of plasmatic vtg in Asian sea bass, Lates calcarifer. Highly specific polyclonal antibodies against purified vtg (antigen) were employed for quantifying the concentration of plasma vtg. The working ranges of the assay were 31.2 to $1000 \mathrm{ng} \mathrm{mL}-1$ with the sensitivity of $6.9 \mathrm{ng} \mathrm{mL}-1$. Antigen concentration of $250 \mathrm{ng} \mathrm{mL}-1$ and antibody dilution of 1:1000 were selected as a workable ELISA after several preliminary test. The ELISA demonstrated precision with intra-and inter-assay Coefficient of Variations (CVs) at 90, 80 and $50 \%$ of binding were less than $8.4(n=9)$ and $12.1 \%(n=5)$, respectively. Serial plasma dilutions from natural vitellogenic females and E2 treated were paralleled to the vtg standard curve (purified vtg) as analyzed by ANCOVA ( $<<0.05)$. No cross-reaction was observed in analyses of male's plasma, indicating non-specific binding. The assay was validated by measuring plasma vtg levels in matured females and males $(n=5)$ obtained during the reproductive season in captive condition. Female's plasma vtg ranges from 0.9 to $1.54 \mathrm{mg} \mathrm{mL}-1$, while no vtg was detected in males plasma. Our results indicated that vtg levels proposed as an indicator for maturing female Asian sea bass, L. calcarifer as well as in female species from genus Lates.
\end{abstract}

Keyword: Development and Validation; ELISA; Vitellogenin; Lates calcarifer. 